\title{
The Demand Forecast and Education Modes of Decision- Making Accounting Personnel--A Case Study
}

\author{
Shengnan Zhang \\ Hohai University Wentian College
}

\begin{abstract}
Accountants, as personnel needed by any enterprises and institutions, have a very broad prospect of employment. However, accounting professionals are currently subject to oversupply and employment difficulties. The reason is that the accounting personnel required by enterprises have changed from the traditional accounting-type personnel to management decision-making personnel who adapt to the economic development. In response to this problem, this paper adopts the methods of literature, questionnaire survey, induction and summarization, etc. for survey and analysis on the demand of management decision-making accounting personnel in the Anhui Region. Based on the survey results, we analyze the forecasts on the current demand for management decision-making accounting personnel and, based on the survey results, put forward approaches for the cultivation of management decision-making personnel and designed the experimental teaching system for management decision-making personnel so as to provide the cultivation of management decision-making personnel meeting the requirements for the development of the Anhui Region and the demands of enterprises in this region with some guidance and suggestions.
\end{abstract}

\section{Keywords}

Accounting Personnel • Personnel Demand Forecasting • Accounting Personnel Training Mode • Anhui Region

\footnotetext{
"This work is supported by Jiangsu Province Social Science Fund Project in China (14EYC006).

${ }^{1}$ Correspondence to: Shengnan Zhang (MA), School of Economic and Management, Hohai University Wentian College, Ma'anshan 243031, China. Email: 423673524@qq.com
}

Citation: Zhang, S. N. (2018). The Demand Forecast and Education Modes of Decision-Making Accounting Personnel-A Case Study. Educational Sciences: Theory \& Practice, 18(5), 1049-1059. http://dx.doi.org/10.12738/estp.2018.5.008 
With the continuous development of the market economy and the increasing degree of internationalization, the traditional accounting-type accountants can no longer meet the needs of enterprises. What enterprises need now are management decision-making accountants integrating such capabilities as accounting, supervision, prediction, analysis and decision making (Hopper, Tsamenyi, Uddin \& Wickramasinghe, 2009), who are not only capable of professional financial management but also capable of solving complicated economic problems and providing relevant basis for the decision making of corporate. They are the main creators of future business values.

China's study and research on management decision-making accountants started nearly 20 years ago, which was relatively late. Therefore, there are fewer relevant references and most of them focus on technical methods instead of the social demands, knowledge ability and the cultivation of management decision-making accounting personnel. Therefore, this article, with this as a starting point, adopts the method of questionnaire survey to survey and analyze the demands of corporate owners in the Anhui region for the work, capability requirements and current situation of management-type accountants (Pierce \& O'Dea, 2003) so as to learn about the current situation of the demands of enterprises for management decision-making accountants. Based on this, we have put forward the approaches to cultivate management decision-making accounting personnel, designed the experimental teaching system for the cultivation of management decision-making accountants, and provided detailed analysis to provide the cultivation of management decision-making personnel in the Anhui Region with some references.

\section{Survey and analysis on the demands for management decision-making accounting personnel in the Anhui region}

\section{Data sources}

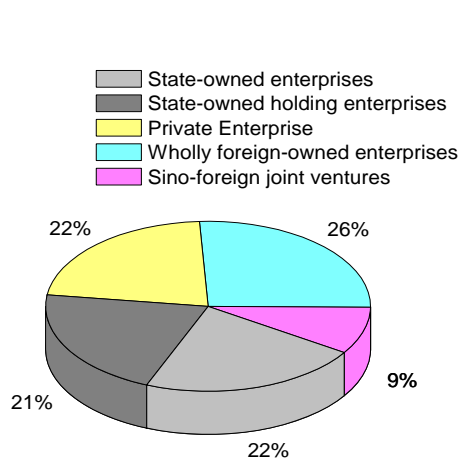

Figure 1. Ownership of the company

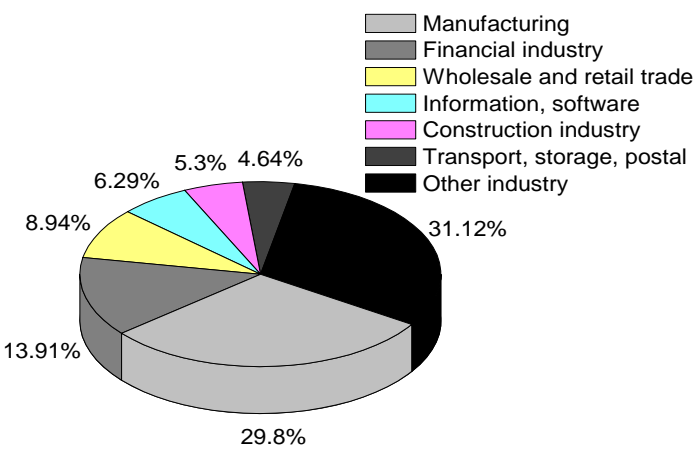

Figure 2. The distribution of various industries

To better understand the demands in the Anhui region for the management decision-making accounting personnel, we issued 350 questionnaires to financial executives in enterprises and public institutions in this area through accounting associations of the Anhui, and 348 effective questionnaires were recovered. Figure 1 shows the proportion of the companies by nature of company ownership, and Figure 2 shows the proportions of various 
industries, with all industries accounting for lower shares (including agriculture, forestry, scientific research, culture, electricity, etc.) classified as "Other industry". From Figure 1 and Figure 2 we can see that the distribution of companies is relatively balanced by nature of company ownership and industry, which can accurately and comprehensively reflect the demand of companies with different natures of ownership and industries for management decision-making accounting personnel.

\section{Survey and analysis on the forecasts of the demands for management decision-making accounting personnel in the Anhui region}

This paper mainly focuses on the competency, professional skills, knowledge importance and functionality of financial personnel (Mendoza \& Bescos, 2001) for survey on managers of enterprises. And the final conclusions are drawn after the analysis.

\section{Competency analysis}

According to the survey results in Figure 3, we can see that among all requirements of corporate managers for financial personnel, the most important one is the decision-making capacity, while they are not satisfied with the decision-making capacity of current financial personnel; The second most important ones are the professional ethics and management skills (Martin \& Witt, 1987). Most financial personnel are able to meet the needs of the enterprises, the management are quite satisfied with them and the importance of creative thinking is also high, but they cannot meet the needs of the enterprises at present. Although the corporate managers don't have high requirements for financial personnel in terms of accounting expertise and skills, communication skills, as well as self-perfection and development ability, they are still not satisfied with the capacities of the financial personnel in these areas. The results of the survey indicate that the enterprises are not satisfied with the decision-making, creative thinking capacities and ability to predict, but are satisfied with their accounting expertise and skills and professional ethics, which just indicates the necessity of the transformation of accounting personnel from the current accounting type to the management decision-making type.

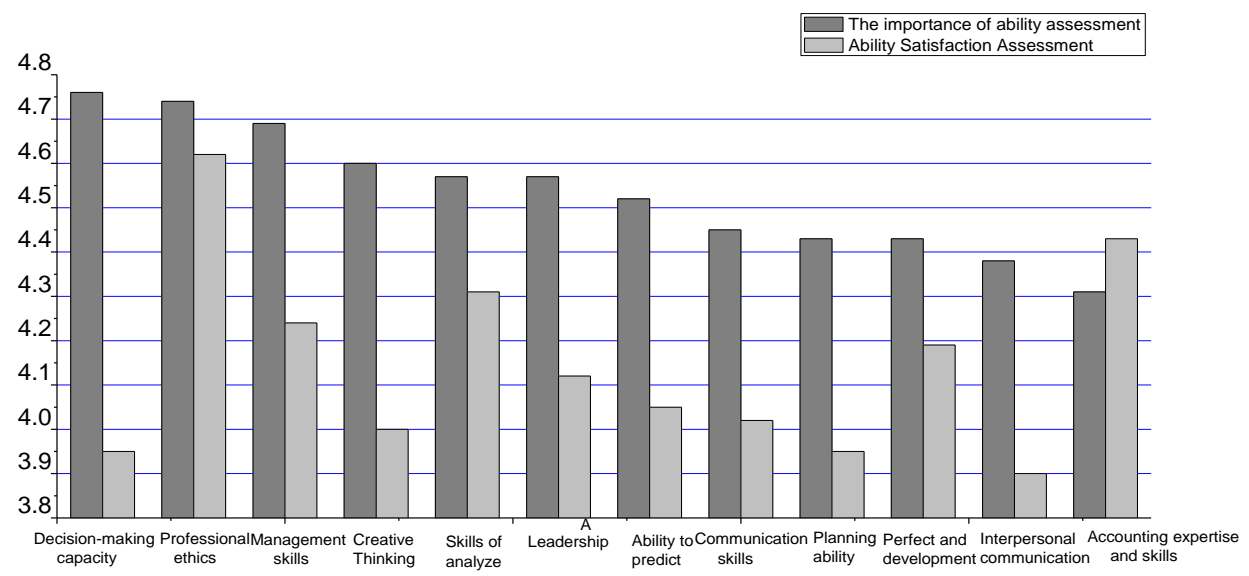

Figure 3. The importance of ability assessment and ability satisfaction assessment 


\section{Analysis on accounting expertise and skills}

As we can see from Figure 4 that presently, corporate managers have high attention and satisfaction for professional competence of financial personnel, such as financial analysis, management capabilities and accounting capabilities, etc., but have low attention and satisfaction for the emerging capabilities, such as data mining, information visualization and market forecasting (Moehrle et al., 2009), indicating that both corporate managers and financial personnel are still not aware of the importance of management decision-making accountants for the development of enterprises and that the role of financial personnel in management and decision making is still limited in the present stage. This also reminds people that they should conform to the needs of the development of the times, pay attention to the transformation of the functions of the financial personnel and the cultivation of relevant capabilities.

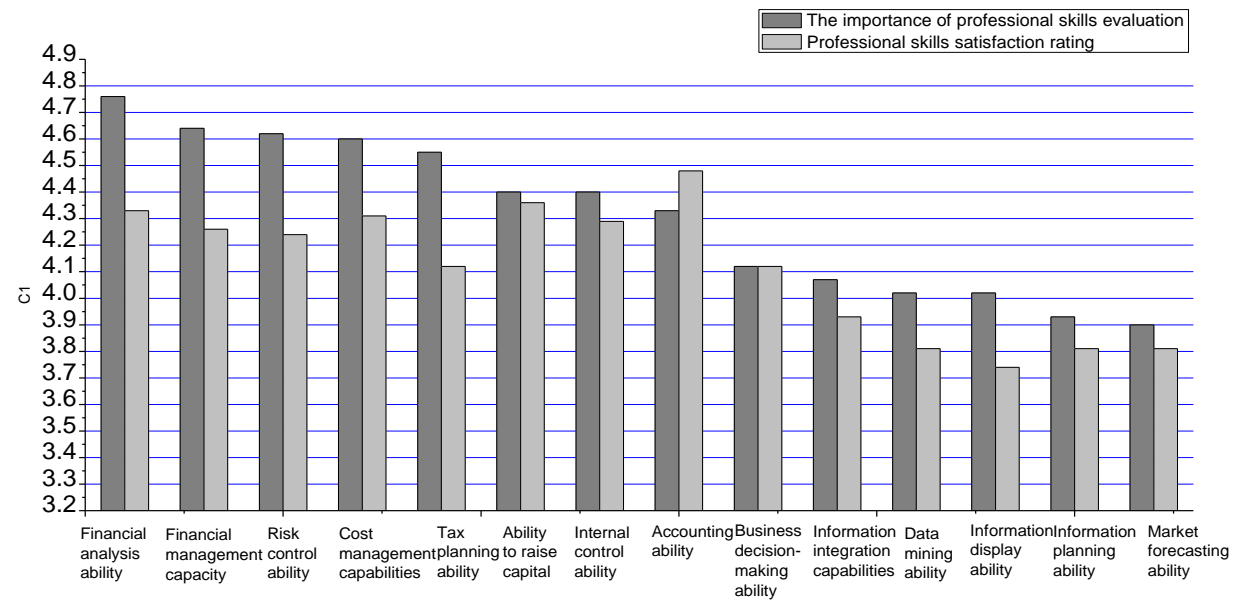

Figure 4. Appraisal of the importance and satisfaction of financial professional skills

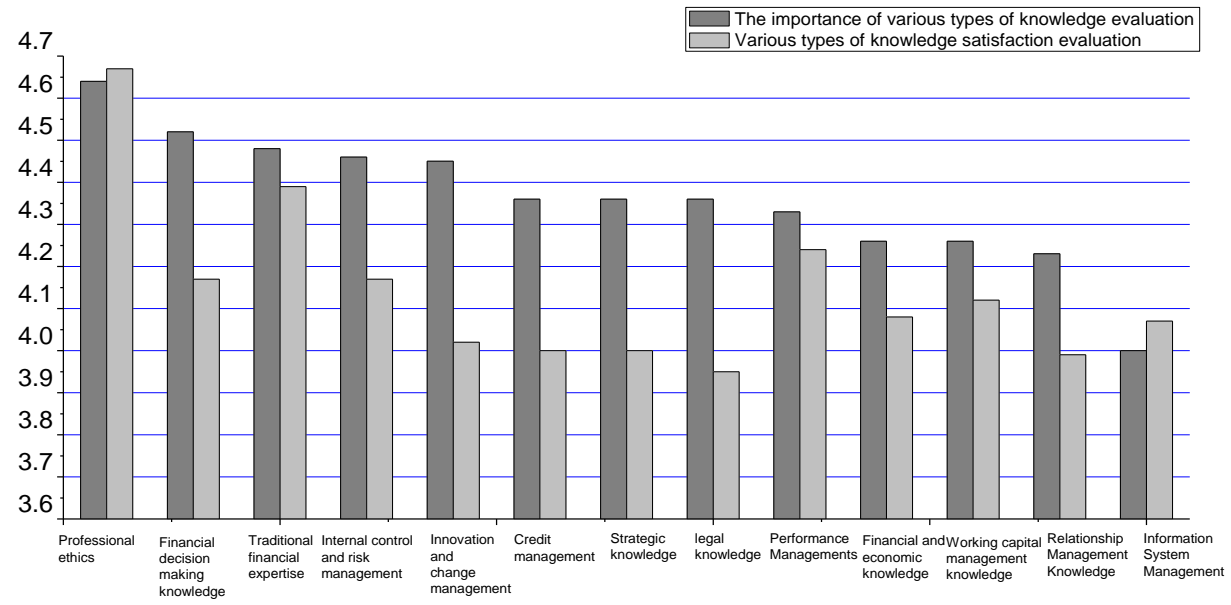

Figure 5. Evaluation of the importance and satisfaction of all kinds of knowledge of financial staff 


\section{Analysis on the importance of knowledge}

By referring to the knowledge frameworks of domestic and foreign accountants' associations for financial and accounting personnel (Ittner \& Larcker, 2001), this paper divides the knowledge of financial personnel into 13 categories, and conducts a survey on the importance and satisfaction of the financial personnel accordingly. The results are shown in Figure 5. From the survey results we can see that the top five categories of knowledge with the highest attention also show high satisfaction and are also necessary basic knowledge for the financial personnel. However, the satisfaction for such frontier knowledge as innovation, management, information, finance, investment decision making (Scapens \& Larcker, 2015) are less satisfied.

\section{Analysis on the performance of management functions of financial departments}

It can be seen from the survey results in Figure 6 that corporate managers think such traditional accounting functions as accounting, analysis, planning and budgeting to be important for the finance departments (Robert \& Kim, 1998) and are also highly satisfied with such functions. However, they attach less importance to and are less satisfied with emerging functions like decision making, forecasting, organizational and control, which means that financial officers remain accounting-type and cannot meet the needs of the companies for innovative management and innovative business.

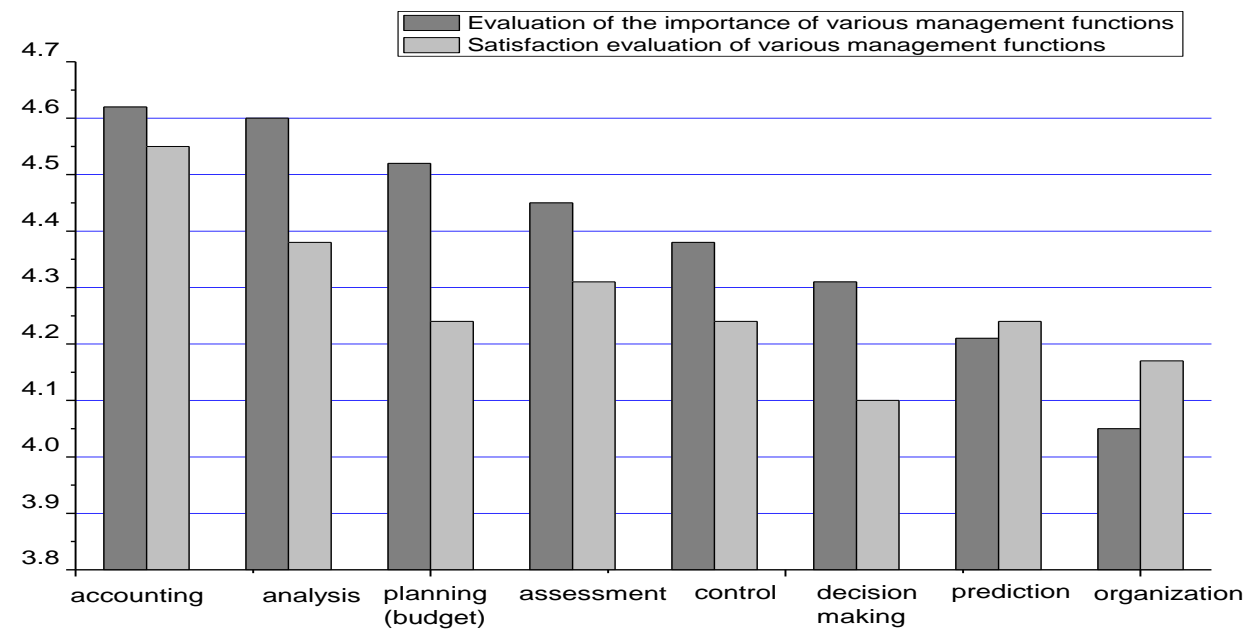

Figure 6. Evaluation of the importance and satisfaction of various financial management functions

Based on the above findings, we find that corporate managers are generally satisfied with the traditional financial work of financial personals. However, with the continuous changes in the economic situation, the "integration of finance and business" in enterprises is deepening, thus leading to higher and higher requirements for the financial personnel, who cannot be limited at the traditional accounting and monitoring capabilities and should need certain capabilities of mining, analysis, forecasting and decision making for data, information and market analysis so as to propose effective advice and suggestions to the management and operation of the enterprises (Guilding, Cravens \& Tayles, 2000). 


\section{Research on cultivation modes of management decision-making accounting personnel}

\section{Cultivation path for management decision-making accounting personnel}

For the cultivation of management decision-making personnel at the present stage, on the one hand, enterprises should attach great importance to the training of related skills on existing financial staff; on the other hand, more importantly, the colleges and universities need to make changes in personnel cultivation system and consummate and improve the personnel cultivation programs based on the cultivation of traditional accountingtype personnel so as to cultivate management decision-making accounting personnel meeting the needs of the enterprises. The implementation path for the cultivation of management decision-making accounting personnel is shown in Figure 7 (Townley, 1995)

To cultivate management decision-making personnel, it is required to coordinately promote the construction of the teachers' team, the optimization of the personnel training programs, the construction of the curriculum resources, the reform of teaching contents and teaching methods as well as the construction of teaching practice bases (Hopwood, 1972), and the ultimate goal is to make the students come into close contact with the actual management and operation of enterprises and evelop their management decision-making ability, which cannot be achieved simply through theoretical teaching, and so this article focuses on the design and analysis for the experimental teaching systems for cultivating management personnel.

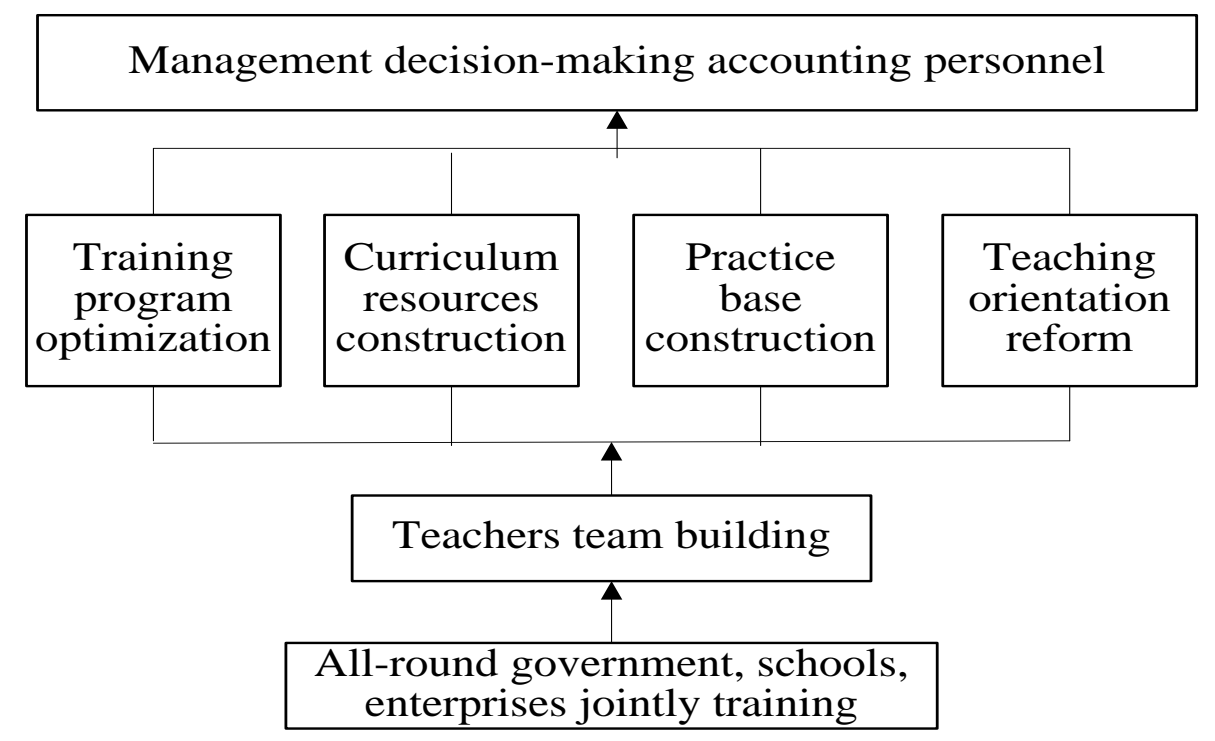

Figure 7. Management decision-making accounting personnel training path framework map 


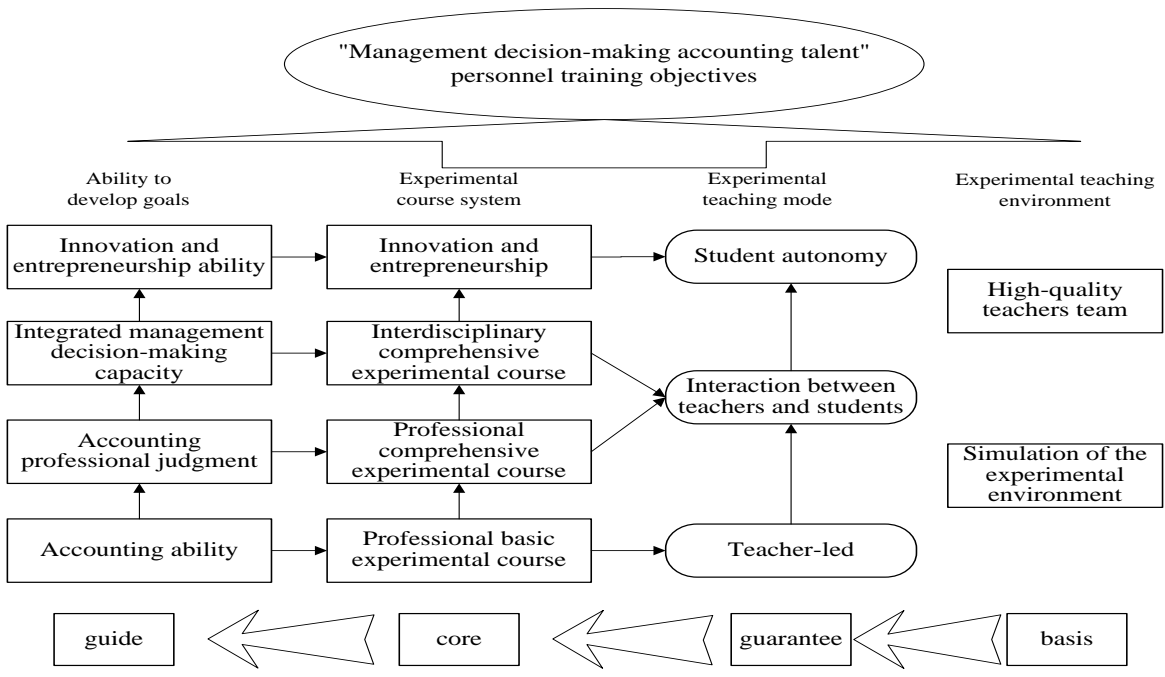

Figure 8. Management decision - making accounting personnel training system design ideas framework

Table 1

The "Four-level" experimental curriculum system driven by ability

\begin{tabular}{|c|c|c|}
\hline $\begin{array}{l}\text { Experimental course } \\
\text { system }\end{array}$ & Experimental course name & Ability to develop goals \\
\hline $\begin{array}{l}\text { Professional basic } \\
\text { experimental course }\end{array}$ & $\begin{array}{l}\text { 1. Basic accounting manual experiment } \\
\text { 2. Financial Accounting Experiment } \\
\text { Cost accounting experiment } \\
\text { 3. Management accounting experiment } \\
\text { 4. Accounting Information } \\
\text { 5. System Experiment } \\
\text { 6. Audit experiment } \\
\end{array}$ & Accounting ability \\
\hline $\begin{array}{l}\text { Professional comprehensive } \\
\text { experimental course }\end{array}$ & 1. Accounting comprehensive training & $\begin{array}{l}\text { Accounting professional } \\
\text { judgment }\end{array}$ \\
\hline $\begin{array}{l}\text { Interdisciplinary } \\
\text { comprehensive } \\
\text { experimental } \\
\text { course }\end{array}$ & $\begin{array}{l}\text { 1. Business operation and decision } \\
\text { making sand table simulation experiment } \\
\text { 2. EPR comprehensive experiment }\end{array}$ & $\begin{array}{l}\text { Comprehensive } \\
\text { management decision- } \\
\text { making ability }\end{array}$ \\
\hline $\begin{array}{l}\text { Innovation and } \\
\text { entrepreneurship }\end{array}$ & $\begin{array}{l}\text { 1. University Science and Technology } \\
\text { Cultural Competition project } \\
\text { 2. College Students Innovative Experimental } \\
\text { Project } \\
\text { 3. University research training program } \\
\text { project } \\
\text { 4. Students entrepreneurship Training } \\
\text { project }\end{array}$ & $\begin{array}{l}\text { Innovation and } \\
\text { entrepreneurship ability }\end{array}$ \\
\hline
\end{tabular}

\section{Basic ideas for the design of the experimental teaching systems for cultivating management design- making accounting personnel}

Based on the findings of the survey on the demand of corporate managers for financial personnel and guided by market demands, we have constructed the experimental teaching systems for cultivating management designmaking accounting personnel (Piercy, 1980). As shown in Figure 8, this experimental teaching system, 
according to the demand of enterprises for the capabilities and knowledge of manage decision-making accounting personnel as well as the capabilities required for the students in different stages, integrates the original experimental teaching system, set up professional basic courses, comprehensive experimental courses, interdisciplinary comprehensive experiment courses and innovative startup courses (Markus \& Teemu, 2002) to fully develop the students' capabilities in accounting, professional judgment, management decision-making and innovation.

\section{Ability-oriented experimental training system}

Through the survey and analysis on the design of experimental teaching in accounting majors of famous colleges and universities in China, this paper has established a four-level experimental curriculum system (Scapens, 2006) according to the actual demands of the enterprises and the targets for the cultivation of management decision-making accountants.

\section{Professional basic experimental course}

The purpose of setting up the basic experimental courses is to cultivate the students' "accounting ability" to make the students master the professional basic courses of a certain major and to reinforce their understanding of the professional knowledge through basic experiments. At present, all accounting majors in different colleges and universities have set up accounting computerized experiment courses based on the EPR software. The software covers most of the main basic courses of accounting majors. To make better use of this software, this paper integrates the application modules of EPR software with the courses (Scapens, 1994), as shown in Figure 9.

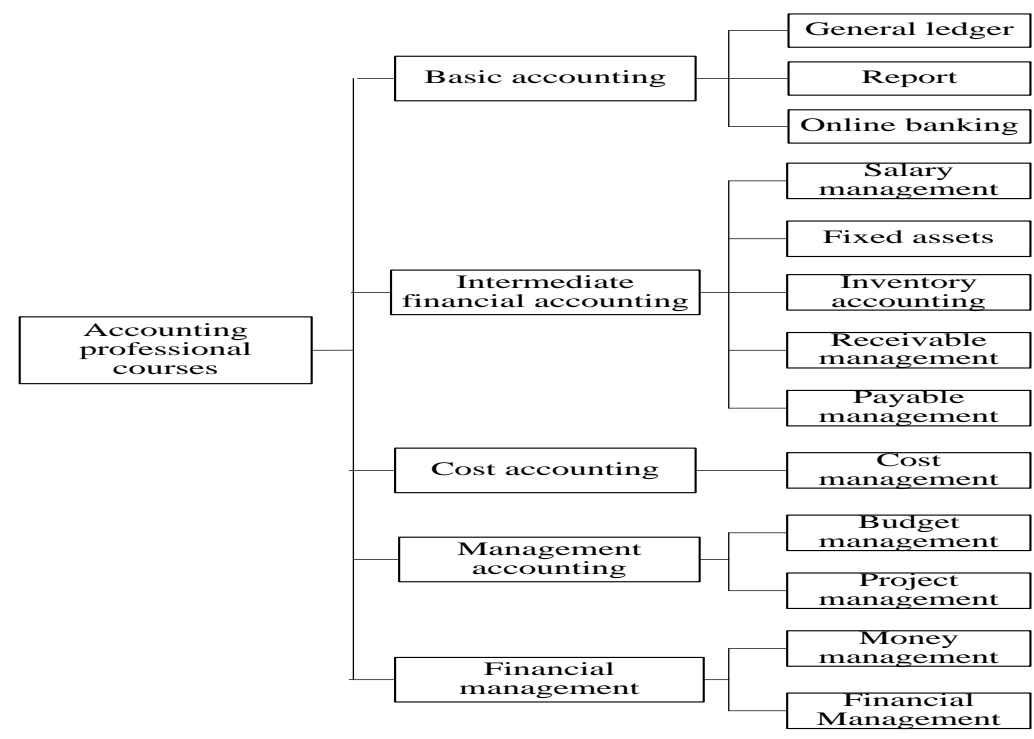

Figure 9. Relationship between accounting module and accounting major course in EPR system module 


\section{Major comprehensive experimental courses}

Professional comprehensive experimental courses are mainly designed to cultivate the students' ability in professional accounting judgment and to make use of the major courses and skills to comprehensively apply accounting methods and skills. The implementation of the comprehensive experimental courses is through virtual enterprise management, with the students competing in teams and playing different roles in the enterprises for planning and operational decision-making of the enterprises and generate financial statements. And the system will generate analysis diagrams for the corporate financial indicators and Dupont analysis. It is planned to make the students fully understand such issues on the financial decision making, forecasting and business management through such simulated operation with role playing and team competition.

\section{Interdisciplinary comprehensive experimental courses}

Interdisciplinary comprehensive experimental courses are designated to train the students to break through the traditional accounting-type thinking and integrate multiple majors and disciplines like business management, such as EPR comprehensive experiments, so that the students can fully improve their comprehensive management and practice capabilities and achieve the ultimate goal for the cultivation of management decision-making accounting personnel.

\section{Innovation and startup programs}

With the acceleration in the construction of an innovative country, colleges and universities are also strengthening the cultivation innovative talent; in order to develop the students' ability of innovation and starting business, it is required to organized the students to participate in more innovative experiment programs, technological and cultural competitions, etc. during which, the students can not only improve their innovation spirit and entrepreneurship, but also development their capacities for management decision-making accountants.

\section{Experimental teaching modes corresponding to curricula}

To truly achieve the effect of experimental teaching, we must adopt different teaching modes according to the specific conditions of the experimental teaching modules in different levels and transform the traditional teaching mode which mainly focuses on "teaching" into one focusing on "learning" so as to truly achieve "student-centered" process of experimental teaching and develop the practical ability of students. For example, the professional basic experimental module should adopt the "teacher-guided" teaching mode, the "teacherstudent interaction" mode should be adopted for comprehensive experimental teaching module, and the "student-based" teaching mode should be mainly adopted for innovation and startup modules.

In a word, there is a long way to go to achieve the cultivation goals of management accounting personnel. Besides the reform of the experimental teaching system, another important factor to promote the achievement of the goals is the high attention from the society, enterprise and governments. 


\section{Conclusion}

With the economic development and the coming of the information age, new requirements have been put forward for accounting, and the traditional accounting-type accountants can no longer meet the requirements of enterprises. It has become an inevitable trend for accountants to transform from the traditional "accounting type" to "management decision-making type". In this paper, we take the demands and cultivation goals for management decision-making accounting personnel in the Anhui region as the research object to survey and analyze the opinions of corporate managers in the Anhui region about the competencies, professional skills, knowledge importance and function performance of current financial personnel. And the following conclusions are drawn:

(1) At present, enterprises pay more attention and are more satisfied with the traditional functions of financial personnel, i.e., accounting, supervision and professional ethics, which indicates that traditional accounting-type accountant can play their roles in the cultivation and practical applications.

(2) The ability of financial personnel in enterprises cannot meet the current demands of enterprises in terms of data analysis, forecasting, decision-making and management, and with the continuous deepening of the "integration of finance and business", relevant requirements are becoming higher and higher and the demand for management decision-making accounting personnel will keep increasing.

(3) Based on the results of business survey, we have proposed the path for colleges and universities to cultivate management decision-making accounting personnel, designed and analyzed in detail the experimental teaching system for the cultivation of management decision-making personnel as reference for the cultivation of management decision-making personnel in the Anhui region.

\section{References}

Chenhall, R. H. \& Langfield-Smith, K. (1998). Adoption and benefits of management accounting practices: an australian study. Management Accounting Research, 9(1), 1-19. http://dx.doi. org/10.1006/mare.1997.0060

Granlund, M. \& Malmi, T. (2002). Moderate impact of ERPS on management accounting: a lag or permanent outcome? Management Accounting Research, 13(3), 299-321. http://dx.doi. org/10.1006/mare.2002.0189

Guilding, C., Cravens, K. S., \& Tayles, M. (2000). An international comparison of strategic management accounting practices. Management Accounting Research, 11(1), 113-135. http://dx.doi. org/10.1006/mare.1999.0120

Hopper, T., Tsamenyi, M., Uddin, S., \& Wickramasinghe, D. (2009). Management accounting in less developed countries: what is known and needs knowing. Accounting Auditing \& Accountability Journal, 22(April), 469-514. http://dx.doi. org/10.1108/09513570910945697

Hopwood, A. G. (1972). The relationship between accounting and personnel management - Past conflicts and future potential. Personnel Review, 1(2), 40-47. http://dx.doi. org/10.1108/eb055199 
Ittner, C. D., \& Larcker, D. F. (2001). Assessing empirical research in managerial accounting: A value-based management perspective. Journal of Accounting \& Economics, 32(1-3), 349-410. http://dx.doi. org/10.1016/s0165-4101(01)00026-X

Martin, C. A., \& Witt, S. F. (1987). Tourism demand forecasting models. Tourism Management, 8(3), $233-246$. http://dx.doi. org/10.1016/0261-5177(87)90055-0

Mendoza, C., \& Bescos, P. L. (2001). An explanatory model of managers' information needs: Implications for management accounting. European Accounting Review, 10(2), 257-289. http://dx.doi. org/10.1080/09638180126636

Moehrle, S. R., Anderson, K. L., Ayres, F. L., Bolt-Lee, C. E., Debreceny, R. S., \& Dugan, M. T. (2009). The impact of academic accounting research on professional practice: An analysis by the aaa research impact task force. Accounting Horizons, 23(4), 411-456. http://dx.doi. org/10.2308/acch.2009.23.4.411

Pierce, B., \& O'Dea, T. (2003). Management accounting information and the needs of managers: Perception of managers and accountants compared. British Accounting Review, 35(3), 257-290. http://dx.doi. org/10.1080/09638180126636

Piercy, N. (1980). Why should a management accountant know anything about marketing?. Management Decision, 18(1), 45-54. http://dx.doi. org/10.1108/eb001233

Scapens, R. W. (1994). Never mind the gap: Towards an institutional perspective on management accounting practice. Management Accounting Research, 5(3-4), 301-321. http://dx.doi. org/10.1006/mare.1994.1019

Scapens, R. W. (2006). Understanding management accounting practices: A personal journey. British Accounting Review, 38(1), 1-30. http://dx.doi. org/10.1016/j.bar.2005.10.002

Scapens, R. W., \& Jazayeri, M. (2015). ERP systems and management accounting change. European Accounting Review, 12(1), 201-233. http://dx.doi. org/10.1080/0963818031000087907

Townley, B. (1995). Managing by numbers: Accounting, personnel management and the creation of a mathesis. Critical Perspectives on Accounting, 6(6), 555-575. http://dx.doi. org/10.1006/cpac.1995.1052 